\title{
IDENTIFIKASI PERBEDAAN HASIL MENTAL MAGERY ANTARA SUAMI DAN ISTRI MENGGUNAKAN THE SIGN TEST
}

\author{
Yulianti ${ }^{1}$, S. N. Zuama² \\ 1Program Studi Matematika Jurusan Matematika FMIPA \\ Kampus Bumi Tadulako Tondo Palu \\ 1julianti_sabang@yahoo.com, 2Shofiyantinurzuama@yahoo.co.id
}

\begin{abstract}
Abstrak
Perkawinan merupakan bertemunya dua manusia yang berbeda dalam hal karakter, kepribadian, prinsip dan tujuan hidup, serta keinginan dan harapannya. Perbedaan-perbedaan inilah yang sering menjadi pangkal sebab dan salah paham yang mengganggu ketenangan dan suasana aman dalam keluarga. Ketidakcocokan menduduki rating tertinggi sebagai faktor penyebab perceraian dibandingkan dengan faktor lainnya. Untuk melihat dampak perceraian bagi pasangan suami istri yang masih terikat perkawinan secara sah, kita dapat menggunakan mental imagery. Mental imagery merupakan kemampuan untuk mengkhayalkan gambarangambaran dalam pikiran setelah stimuli-stimuli asli tidak dapat dilihat lagi. Metode yang digunakan dalam penelitian ini yaitu statistik deskriptif dan The Sign Test. Dan diperoleh hasil bahwa tidak ada perbedaan hasil mental imagery yang signifikan antara suami maupun istri mengenai dampak perceraian. Baik suami maupun istri mayoritas berada pada kategori sedang .
\end{abstract}

Kata Kunci $\quad$ : Perkawinan, Dampak Perceraian, Mental Imagery, Statistik Deskriptif, The Sign Test.

\section{Pendahuluan}

Pernikahan banyak ditentukan oleh tekad baik kedua pasangan yang akan membentuk dan menciptakan pernikahan yang baik dan harmonis. Menurut Armi Yanti (alumni Fakultas Psikologi Universitas Surabaya, 2008), dari data yang diperolehnya dalam penelitian yang sama mengenai mental imagery suami dan istri mengenai dampak perceraian, ternyata ada pergeseran tren yang menarik. Seiring tahun berjalan, jumlah perempuan yang mengajukan gugatan cerai terus meningkat jika dibandingkan dengan jumlah laki-laki yang mengajukan talak. Menurutnya, perempuan makin lama makin berani menyatakan keinginannya untuk berpisah. Sementara jumlah cerai talak yang diajukan pihak suami nyaris tidak berubah. Ketidakcocokan menjadi alasan terbanyak dalam kasus 
perceraian. Ketidakcocokan menduduki rating tertinggi sebagai faktor penyebab perceraian dibandingkan dengan faktor lainnya seperti adanya pihak ketiga, kekerasan dalam rumah tangga, dan lain-lain. Menurut Gottman (Bachtiar, 2004), momok perceraian tersebut akan terwujud jika masing-masing selalu melakukan kritik yang intinya menyalahkan pasangan, penghinaan, pembelaan diri, dan membangun tembok-tembok pembatas untuk tidak berhubungan lagi.

Untuk melihat dampak perceraian bagi pasangan suami istri yang masih terikat perkawinan secara sah, kita dapat menggunakan mental imagery atau pembayangan. Selanjutnya, akan dilakukan uji statistik nonparametrik untuk mengetahui apakah ada perbedaan hasil mental imagery antara suami dan istri mengenai dampak perceraian.

\section{Metode Penelitian}

Dalam penelitian ini, alat dan bahan pengumpulan data yang digunakan dalam memperoleh data dari responden (pasangan suami istri yang akan bercerai) adalah berupa daftar pertanyaan (kuesioner) yang digunakan untuk mengetahui respon dari responden secara langsung. Selanjutnya akan dilakukan uji validitas dan reliabilitas data. Data yang valid dan reliabel kemudian akan diolah secara manual dengan menggunakan Metode The Sign Test untuk mengetahui apakah ada perbedaan mental imagery antara suami dan istri mengenai dampak perceraian.

\section{Hasil dan Pembahasan}

Ada 3 aspek dampak perceraian yang diperhatikan dalam penelitian ini yaitu aspek penyesuaian diri, traumatik, dan aspek perubahan peran dan status. Tabel Silang Komposisi Responden Berdasarkan Status dan Aspek Dampak Perceraian menunjukkan bahwa pada aspek penyesuaian diri, baik kelompok suami maupun istri yang tergolong kategori tinggi berjumlah 0 , pada kategori sedang jumlah suami yang tergolong pada kategori ini adalah $7,2 \%$ dan istri $6,1 \%$, sedangkan pada kategori rendah, jumlah suami yang tergolong kategori rendah berjumlah $9,4 \%$ dan istri sebesar $10,6 \%$. Pada aspek traumatik, jumlah kelompok suami yang tergolong kategori tinggi sebesar $5 \%$ dan pada kelompok istri sebesar $9,4 \%$, selanjutnya pada kategori sedang, jumlah suami yang termasuk pada kategori ini sebesar $8,9 \%$ dan istri sebesar $6,1 \%$, sedangkan kelompok suami yang tergolong pada kategori rendah ada 2,8\% dan istri sebesar $1,1 \%$. Terakhir, pada aspek perubahan peran dan status, jumlah suami yang tergolong pada kategori tinggi sebesar $3,9 \%$ dan istri sebesar $2,8 \%$, pada kategori sedang,kelompok suami yang termasuk pada kategori ini ada $12,2 \%$ dan istri sebesar $13,9 \%$, sedangkan pada kategori rendah kelompok suami sebesar $0,6 \%$ dan istri sebesar $0 \%$. 
Dari hasil yang diperoleh, dapat disimpulkan bahwa pada aspek penyesuaian diri, baik suami maupun istri mayoritas berada pada kategori rendah, artinya suami dan istri tidak memiliki mental imagery yang cukup baik mengenai dampak perceraian dari aspek penyesuaian diri,dimana sebagian dari mereka akan merasa kesulitan dalam proses penyesuaian diri jika perceraian terjadi. Selanjutnya dari aspek traumatik dapat dilihat bahwa sebagian besar suami tergolong pada kategori tinggi dan istri mayoritas berada pada kategori sedang, sehingga dapat disimpulkan bahwa baik suami maupun istri memiliki mental imagery yang baik mengenai aspek traumatik ini. Namun dibanding istri, suami memiliki kesiapan mental yang lebih baik dan istri lebih mudah mengalami trauma dibanding suami jika seandainya perceraian terjadi dalam rumah tangga mereka. Terakhir, pada aspek perubahan peran dan status, suami dan istri mayoritas sama-sama berada pada kategori sedang yang artinya baik suami maupun istri sama-sama mempunyai mental imagery mengenai dampak perceraian pada aspek perubahan peran dan status, dimana jika seandainya perceraian terjadi pada pernikahan mereka, mereka sebagian besar sudah cukup siap dengan perubahan peran dan status yang akan mereka sandang. Dari tabel tersebut dapat disimpulkan bahwa ada perbedaan hasil mental imagery antara suami dan istri, namun perbedaan tersebut tidak signifikan dan perbedaan tersebut tidak terlalu besar, sehingga selanjutnya dilakukan pengujian statistik nonparametrik design test untuk memperjelas kesimpulan tersebut. Hasil pengujian statistik non parametrik mengggunakan The Sign Test sebagai berikut :

Hipotesis :

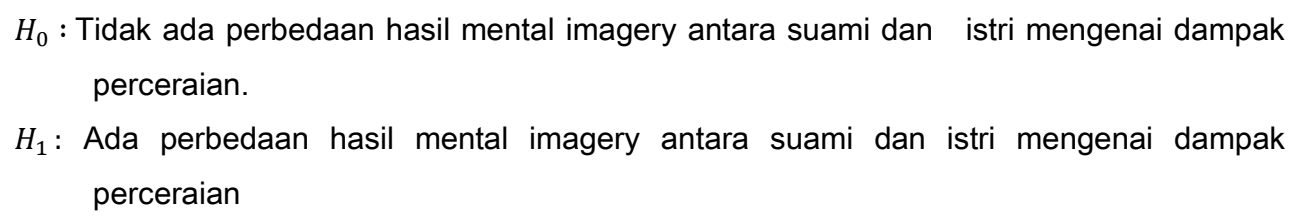

Tabel 1 : Skor Mental Imagery Pasangan Suami Istri

\begin{tabular}{|c|c|c|c|}
\hline No & $\begin{array}{c}\text { Skor mental imagery } \\
\text { suami }\end{array}$ & $\begin{array}{c}\text { Skor mental imagery } \\
\text { istri }\end{array}$ & Perubahan tanda \\
\hline 1 & 44 & 26 & - \\
\hline 2 & 29 & 45 & + \\
\hline 3 & 32 & 23 & - \\
\hline 4 & 37 & 38 & + \\
\hline 5 & 27 & 41 & + \\
\hline 6 & 46 & 41 & - \\
\hline 7 & 32 & 35 & - \\
\hline
\end{tabular}




\begin{tabular}{|c|c|c|c|}
\hline 8 & 37 & 39 & + \\
\hline 9 & 34 & 30 & - \\
\hline 10 & 38 & 39 & + \\
\hline 11 & 37 & 39 & + \\
\hline 12 & 42 & 47 & + \\
\hline 13 & 33 & 36 & + \\
\hline 14 & 34 & 31 & - \\
\hline 15 & 39 & 39 & 0 \\
\hline 16 & 34 & 40 & + \\
\hline 17 & 41 & 42 & + \\
\hline 18 & 32 & 27 & - \\
\hline 19 & 36 & 47 & + \\
\hline 20 & 28 & 36 & + \\
\hline 21 & 44 & 27 & - \\
\hline 22 & 35 & 34 & - \\
\hline 23 & 29 & 45 & + \\
\hline 24 & 37 & 41 & + \\
\hline 25 & 34 & 42 & + \\
\hline 26 & 30 & 31 & + \\
\hline 27 & 25 & 40 & + \\
\hline 28 & 43 & 40 & - \\
\hline 29 & 29 & 40 & + \\
\hline 30 & 40 & 27 & - \\
\hline
\end{tabular}

Pada tabel skor mental imagery suami dan istri, Probabilitas memperoleh tanda $(+)$ atau tanda $(-)=0,5$, maka dari 30 pasang responden yang diteliti tersebut diperoleh mean dan standar deviasi sebagai berikut :

$$
\begin{aligned}
\operatorname{Mean}(\mu) & =n \cdot p \ldots \ldots \\
& =30(0,5) \\
& =15
\end{aligned}
$$

Standar deviasi $(\sigma)=\sqrt{n \cdot p \cdot q}$

$$
\begin{aligned}
& =\sqrt{(30)(0,5)(0,5)} \\
& =2,74
\end{aligned}
$$


Dari hasil pengamatan, diperoleh jumlah tanda $(+)=18$, maka $X$ akan terletak pada $X=17,5$. Maka test statistiknya adalah sebagai berikut :

$$
\begin{aligned}
Z_{H} & =\frac{X-\mu}{\sigma} . \\
& =\frac{17,5-15}{2,74} \\
& =0,91
\end{aligned}
$$

Nilai kritis bila $\alpha=5 \%$ (pengujian dilakukan dengan 2 sisi), maka nilai kritis $= \pm Z 1 / 2 \alpha= \pm 1,96$

$H_{0}$ diterima bila $-1,96 \leq Z_{H} \leq=+1,96$

$H_{0}$ ditolak bila $Z_{H}>+1,96$ atau $Z_{H}<-1,96$

Kesimpulan :

$H_{0}$ diterima karena $-1,96 \leq Z_{H} \leq=+1,96$.

Hal ini berarti bahwa tidak ada perbedaan hasil mental imagery antara suami dan istri mengenai dampak perceraian.

\section{Kesimpulan}

Berdasarkan hasil analisis data dan pembahasan di atas, maka kesimpulannya adalah sebagai berikut :

- $\quad$ Tidak ada perbedaan hasil mental imagery yang signifikan antara suami dan istri mengenai dampak perceraian yang ditunjukkan baik melalui hasil uji statistik deskriptif maupun hasil uji nonparametrik The Sign Test.

- Berdasarkan table 4.5 menunjukkan bahwa hasil mental imagery suami maupun istri mengenai dampak perceraian sebagian besar tergolong pada kategori sedang. Hal ini menunjukkan bahwa baik suami maupun istri mempunyai mental imagery yang cukup kuat dan kesiapan mental yang cukup baik jika perceraian terjadi dalam rumah tangga mereka.

- Dari ketiga aspek dampak perceraian, aspek perubahan peran dan status adalah aspek yang paling banyak berpengaruh pada hasil mental imagery antara suami dan istri.

\section{Daftar Pustaka}

[1]. Bachtiar. A.. 2004. Menikahlah, Maka Engkau Akan Bahagia!. Yogyakarta. Saujana.

[2]. Yanti. A.. 2008. Perbedaan Mental imagery Suami dan Istri dalam Menghadapi Perceraian. Surabaya. Alumni. 